\title{
Restorying the purpose of business: The agenda of the UN Global Compact
}

\author{
Author: \\ Prof Oliver F. Williams ${ }^{1,2}$ \\ Affiliation: \\ ${ }^{1}$ Center for Ethics and \\ Religious Values in \\ Business University of \\ Notre Dame, United States \\ of America \\ ${ }^{2}$ Stellenbosch University, \\ South Africa \\ E-mail: \\ williams.80@nd.edu \\ DOI:
}

10.15249/12-2-195

\section{Keywords:}

business and society: restorying the purpose of business; moral norms for business; United Nations Global Compact; Sustainable Development Goals

\section{Abstract}

The article argues that there is a paradigm shift in our understanding of the role of business in society and that this move is best understood as a "restorying" of the purpose of business. The term "story" is used here to refer to a pattern of meaning. The organisation leading this movement is the United Nations Global Compact with its ten principles and 17 Sustainable Development Goals (SDGs) designed to overcome global poverty. To illustrate an example of how stories can inspire action and how challenging the decisions involved might be, there is a discussion of how oil and gas companies wrestle simultaneously with trying to realise SDG 7, access to energy, while also meeting the concerns of SDG 13, combating climate change. The article concludes on a hopeful note that the UN Global Compact, with over 9600 companies in 161 countries "restorying" the purpose of business, can facilitate a better life for all.

\section{Introduction}

In the last thirty years, society has been asking more of business organisations. There has been an evolving understanding of the role and responsibilities of business. As will become evident, I call this work in progress a "restorying" of the purpose of business.

To be sure, there are passionate advocates of the emerging role of business in society. "It's time that beliefs and theories about business catch up with the way great companies operate and how they see their role in the world today" (Kanter, 2011:68). This quote is from Rosabeth Moss Kanter, a major scholar at Harvard Business School, and sets the stage for the thoughts 
which follow. Kanter captures the spirit of our times, which asks more of business than just creating wealth. Kanter argues that the best businesses employ not only a financial logic, but also "a social or institutional logic". "Institutional logic holds that companies are more than instruments for generating money; they are also vehicles for accomplishing societal purposes and for providing meaningful livelihoods for those who work in them" (Kanter, 2011:68). The suggestion here is that we move beyond the neo-classical theory of the firm where the purpose of business is to single-mindedly create wealth to a broader understanding of its purpose, what some specify as the creation of sustainable value for stakeholders (Williams, 2014:30-50). Although a full-blown theory of business is a work in progress (Donaldson \& Walsh, 2015:181-207), the reflections here will discuss how what is going on today might best be understood as a "restorying" of the purpose of business (Driscoll \& McKee, 2007). While this new understanding of the purpose of business is not in practice in all firms, I argue that it is catching on in the corporate world and is the guiding vision of the United Nations Global Compact (UNGC).

\subsection{The Global Compact in brief}

All the institutions of the United Nations have a common vision stated in the Preamble to the Charter: "to reaffirm faith in fundamental human rights, in the dignity and worth of the human person" (UN Preamble, 2018; Williams, 2014). The UNGC is the largest corporate social responsibility venture in the world with over 9600 businesses in 161 countries committed to advancing human rights, labour issues, environmental concerns, and anti-corruption, particularly in developing countries. The first principle of the Principles for Responsible Management Education (PRME), the business school arm of the UNGC, states it well: "We will develop the capabilities of students to be future generators of sustainable value for business and society at large and to work for an inclusive and sustainable global economy" (UN PRME, 2007; Williams, 2004). Note that the purpose of business here is not simply to make money. The key document of the Global Compact advancing its mission, The Blueprint for Corporate Sustainability Leadership, reminds signatory companies that "Corporate sustainability is defined as a company's delivery of long-term value in financial, social, environmental and ethical terms" (UN Global Compact, 2011).

\subsection{Some history}

One symptom of this change in society's expectations of business was the activists' dramatic protests in the 1990s against the so-called "sweatshops". Nike's factories in developing countries that manufactured its high-end athletic apparel were often the poster child for this bad behaviour. The claim was that these sweatshops paid their employees poorly, neglected normal health and safety conditions, and generally had little respect for the dignity of the workers (Zadek, 2004).

In the 1990s, activists continued to protest the abuses of multinational companies in developing countries. The move of MNCs to developing countries was often referred to as globalisation, a term signifying not only the movement of capital, but also of 
goods and services, technologies, and people. There is no doubt that globalisation was responsible for advancing many people in poor countries out of dire poverty because of its wealth-creating and job-creating abilities. Yet, this rise in prosperity was often accompanied by bankruptcies, loss of jobs, corporate downsizing, take-overs, human rights abuses, environmental degradation, and disruption of communities. While globalisation caused a huge expansion of the global economy as companies outsourced into poor developing countries, there were growing reports of human rights violations in the outsourced companies. The problem was that without a world government, there was no common agreement on the appropriate moral norms that would guide business in its new environment. Are multinational companies responsible for the human rights violations of their subcontractors? While NGOs argued that they were responsible, Nike argued the typical MNC position and said they were not morally responsible. What are the appropriate moral norms for guiding a company's environmental practice where there is no enforced legal norm in a country? In the late 1990s, it was clear that there was a need for some global organisation to promote and enhance moral norms to guide MNCs in developing countries (Williams, 2014).

In 1999, the United Nations, under the leadership of Kofi Annan, then secretarygeneral, following the work of some business leaders and academics, proposed that we see the problem in a wider context: businesses must see themselves as connected to a larger community and guided by a higher purpose than simply making money. In Annan's words:

Let us choose to unite the power of markets with the authority of universal ideals. Let us choose to reconcile the creative forces of private entrepreneurship with the needs of the disadvantaged and the requirements of future generations.

(Annan, 1999)

Annan was suggesting that if business would embody values such as trust, fairness, integrity, and respect for people, rather than being a problem, globalisation could increase and diffuse the benefits of global economic development. It was with this in mind that Annan proposed in 1999 at the World Economic Forum that the UN and business together form "a global compact of shared values and principles to give a human face to the global market”. The UN Global Compact, officially launched in 2000, consists of 10 principles guiding a company in areas of human rights, labour, standards, the environment and anti-corruption (Annan, 1999).

\section{The UN Global Compact: an exercise in the restorying of business}

While Kofi Annan and other officials of the UN, to my knowledge, never used the term "restorying," in my view, their efforts in the Global Compact are a restorying project. The term "story" is used here to refer to a pattern of meaning that help us understand what our lives are all about (Boje, 1995; Boyce, 1996; Denning, 2006; Fleming, 2001). Most of us employ the logic and patterns of several stories to put form, focus and structure to our 
experience; for example, to say you are a father, a business person and a good citizen, means that you take as your own the logic and patterns of each of these stories (Williams \& Houck, 1978). For example, the "father story" has a certain set of role expectations and a pattern of meaning that is commonly accepted. The point being made here is that the "business story" is in flux with new and expanded expectations commonly held.

Until relatively recently, the business "story" commonly accepted was that articulated well by the economist Milton Friedman. Friedman states that the purpose of business is "to make as much money as possible while conforming to the basic rules of the society, both those embodied in law and those embodied in ethical custom" (Friedman, 1970). "Ethical custom" for Friedman means the honesty, fidelity and integrity required for markets to function. He does not mean employing social and human values in economic decisions. For Friedman, advancing social and human values is solely a government role (Friedman, 1962). Thus, the business "story" is single-mindedly focused on making money for shareholders and other stakeholders are relevant here only insofar as advancing their welfare will result in better returns for shareholders. As one author puts it: "In a sense, workers are prisoners of one storyline in which serfs (workers) are completely loyal to the lord of the fiefdom (corporation) and, therefore, the status quo is maintained at all costs" (Driscoll \& McKee, 2006:210). On the other hand, this one storyline explicitly defines how to gain acceptance in the corporation and with its clearly defined standards of excellence and rules for advancement, it has been attractive for generations largely because its logic has meaning which brings security and a kind of peace.

The changing values of society, however, were slowly undermining the traditional business story and a new storyline was emerging. Astute business leaders such as John Mackey, CEO of Whole Foods, and Bill Gates, founder of Microsoft, were attuned to the new expectations for business and argued for a broader role of business in society. The theoretical perspective of this change was advanced by R. Edward Freeman. The purpose of business was not simply to make money for shareholders, but to create sustainable value for all relevant stakeholders (Mackey \& Sisodia, 2013; Gates, 2008; Freeman, 1984). So, not only shareholders, but also employees, suppliers, customers, the environment and the community are the concern of business.

\section{A higher purpose for business}

Kofi Annan, with his appeal to the 1948 Universal Declaration of Human Rights (UDHR) as the underpinnings of the Global Compact, was trying to explicitly connect business to the larger community and to provide a higher purpose. It is important to consider the genesis of the UDHR in order to understand the restorying process. After experiencing the horrors of World War II and the Holocaust, scholars and political leaders came together at the UN to find a way to try to avoid such an affront to human dignity in the future. The goal was to outline what it takes for the full flourishing of human beings. What states of the person and the community are desirable or, in other words, what values are crucial for human fulfilment, respecting the intrinsic value of the person? The basic value 
was to have a community where people live and work together in mutual fulfilment. Realising this basic value requires a host of other values such as trust, a just social order, honesty, health, openness, and friendship. This "story" and its vision of the good life, was the background for the UDHR (Morsink, 1999). The Global Compact considers this the "master" story, the story that puts limits on and guides the business story.

What the UN did in 1948 was to proclaim what it would take to realise the values of a humane community. To promote and protect these values, certain principles and rules would be essential and these were proclaimed as human rights. These human rights were designed to protect the values essential for a humane life, to promote the "story" that thoughtful people believed could enable human flourishing.

The point here is to recognise that Kofi Annan was trying to put the business story in the context of a bigger and more meaningful story. His emphasis on the UDHR and subsequent amplifications to human rights were designed to help people in business feel part of a larger community and a more meaningful story. This "story" of a humane community appeals not only to the mind, but also the heart. Principles are abstractions from the story designed to protect and promote the values, appealing primarily to the intellect with little influence on the affective dimension of the person. The insight that a way of life is largely passed on by storytelling was fully understood by religious leaders, for example Jesus Christ, Buddha and Mohammed (Hauerwas, 1975; McClendon, Jr., 1974). This insight has been retrieved by the UN Global Compact.

\subsection{The Sustainable Development Goals: stories to transform our world}

On 25 September 2015, the United Nations General Assembly passed a set of broad goals "to end poverty, protect the planet and ensure that all people enjoy peace and prosperity" (UNGC, 2015a). Known as the Sustainable Development Goals (SDGs), the 17 goals each tell a story of how life without human rights causes suffering and deprives the person of living in a community envisaged in 1948 by the UDHR. These 17 stories depicted in videos on the UN website are designed to inspire and empower, engendering new understanding and action. Businesses engaging in meeting the SDG goals will have employees who are able to see the connection of their life's work with many other stakeholders, especially the least advantaged. Figure 1 is from a UNGC document and lists the ten principles of the UN Global Compact, the 17 SDGs and the possible linkages between them. The SDG stories put flesh on the 10 principles. Principles are abstractions from the stories and just as a skeleton could never convey the beauty of a complete person, so a principle could never capture the complexity of human action (UNGC, 2016).

Figure 1 illustrates some of the primary linkages between the UN Global Compact Ten Principles and the contribution that these can make towards the achievement of the SDGs. By respecting and supporting universal principles, UN Global Compact business participants can play an important role in helping to realise the SDGs (UNGC, 2016). 


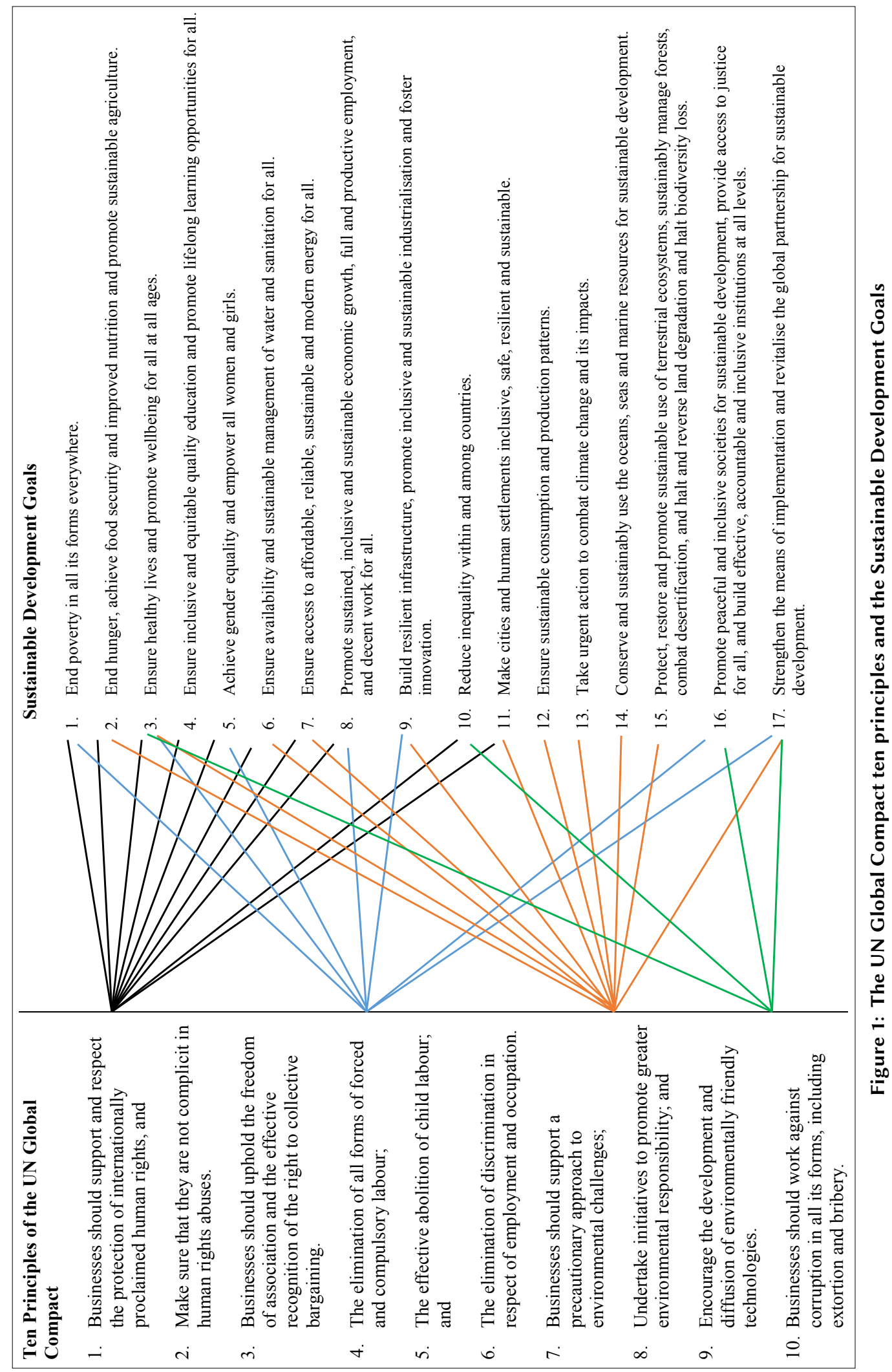




\subsubsection{UNGC action platforms}

It became clear after several years working with the SDGs that a more formal structure might be helpful to advance the completion of the goals. In 2018, Action Platforms, bringing together business, UNGC Local Networks, civil society groups, experts, governments and UN partners, were formed in 10 areas. These areas are: Breakthrough Innovation for the SDGs; Pathways to Low-Carbon and Resilient Development; Health is Everyone's Business; Reporting on the SDGs; Financial Innovation for the SDGs; Decent Work in Global Supply Chains; Business for Humanitarian Action; Water Security through Stewardship; Business Action Platform for the Ocean; and Peace, Justice and Strong Institutions. The 10 platforms are designed to realise SDG 17, Partnerships for the Goals - "strengthen the means of implementation and revitalize the global partnership for sustainable development" (UNGC, 2018). The Action Platforms will enable the restorying of business to proceed at a faster pace and, hopefully, yield much fruit. In a way, each Action Platform is a story, a chapter in the master story, which offers a vision and values for the good life.

\subsection{The challenge of restorying business}

As indicated above, the new "story" of business is to create sustainable value for stakeholders and not simply for the stockholder. The 17 SDGs dramatically portray the suffering of those who might benefit from actions from the business story and are designed to inspire collective thought and action on the part of the powerful to alleviate the deprivation. The hope is that in most cases this business action will be creating shared value where both business and those in deprivation will attain value. Business through creativity and innovation will earn more value and those deprived will gain a better life.

To illustrate the narrative quality of experience and how stories can inspire action, even in the face of apparent conflict, it may be helpful to discuss one issue from the oil and gas industry. In fact, conflicts often arise as companies try to advance the SDGs. Consider one example, the apparent conflict between Goal 7 and Goal 13. Goal 7, Affordable and Clean Energy, seeks to "ensure access to affordable, reliable, sustainable and modern energy for all". Goal 13, Climate Action, asks the global community to "take urgent action to combat climate change and its impacts by regulating emissions and promoting developments in renewable energy" (UNGC, 2015a). The UN website on the Sustainable Development Goals has several stories for each of the 17 SDGs, which dramatically portray the suffering that people undergo when they live their lives outside of the good life, the master story outlined by the UDHR vision. For Goal 7, there are three stories: "Supporting Mali's women to adapt to climate change"; "Solar empowerment across countries"; and "Honduran women light the way" (UNGC, 2015b). For Goal 13, there are several stories, including: Peru's: "Protectors of our planet's lungs"; Maldives: "Drones for social good"; Montenegro: "A guilt-free holiday"; and Somalia: "In search of water" (UNGC, 2015c). 
The suffering endured by those living without electricity can be intense and their numbers are surprisingly high. Of the 1.06 billion people without electricity, $80 \%$ of them live in just 20 countries. Excluding North Africa, 37\% of Africans are without electricity. In Haiti, $38 \%$ and, in Sudan, $45 \%$ lack electricity. Only $85.3 \%$ of the world's people have electrification.

\subsection{Practical wisdom}

It has been said that energy is "the golden thread" connecting growth, social equity and environmental sustainability. About half of all energy now provided to the global village is from the oil and gas industry. Yet, the carbon emissions from fossil fuels are a factor in climate change and this is becoming a serious threat. What is an oil and gas company to do? There is clearly a conflict of values; energy from oil and gas provides the possibility of a life lived with dignity, while it also adds to global warming, which threatens health and safety. Knowing how to advance electrification and balancing it against the threat of global warming requires experience, and is what Aristotle called Phronesis or practical wisdom or prudence (Aristotle, 1999). What decision is most likely to deliver the wellbeing sought?

Michael A. Santoro developed "A Fair Share Theory of Human Rights" in his work with ethical issues in China (Santoro, 1998:25-54). Adapting his work to solve the conflict of values for the oil and gas business as it strives to increase access to energy in the world, there are three principles to consider. The premise is that everyone has a right to have their human dignity respected and, in our time, that right involves access to affordable electricity, as well as health and safety. What is in question is who should meet that right, at what social and financial cost, and how?

The suggestion here is that a company deciding whether to accept the challenge of advancing the master story of the UDHR and, more specifically, advancing Goals 7 and 13 of the SDGs should consider the following:

1. Relationship to those whose rights are not met, i.e. in this case, the 1.06 billion people without electricity.

2. The likely effectiveness of the company in remedying the problem.

3. The capacity of the company.

While the first principle is often thought of in spatial terms, in our time it perhaps best refers to the whole array of social expectations that society has of business. Where there is power, there is responsibility, is the common expectation (Globe Scan, 1999). The second and third principles express the common-sense notion that, while companies must do something, they should not be asked to do more than they are capable of doing effectively. 
While there are many companies in the UN Global Compact that might be discussed to illustrate how practical wisdom can deliver a sustainable future to our planet, this article will discuss one: Total S.A. Based near Paris, the company operates in 130 countries and has over 15000 service stations. With a revenue of over $\$ 125$ billion (U.S.), the company has 100000 employees.

Total is clear on its mission:

At Total we are committed to finding solutions to the challenge of climate change, while also supporting social and economic development around the world by providing energy that's affordable and sustainable.

(Total, 2017)

The company has reduced its own greenhouse gas (GHG) emissions by $23 \%$ since 2010 , stopped producing coal in 2015, and focused on increasing the proportion of natural gas (the fossil fuel with the least emissions) in the energy mix. In 2014, Total, with other major oil producers, formed the Oil and Gas Climate Initiative $(\mathrm{OGCl})$. Today, with nine companies producing more than one-sixth of the oil and gas in the world, this initiative works toward a reduced carbon-intensive economy. Sharing best practices in energy efficiency, developing renewable energy and enhancing $R \& D$ are part of this collective effort. Total also offers a government policy framework that will level the playing field and provide incentives for all in the industry to participate. Many argue that some sort of a carbon tax is essential to lower GHGs. Total has an ongoing lobby not only with governments, but also with other oil companies with the goal of engendering collective action to overcome climate change.

While tackling climate change, Goal 13 of the SDGs, is a priority for Total, equally important is Goal 7, "access to affordable, reliable, sustainable and modern energy for all”. In following Total's response to the challenge of Goal 7, it is clear that the company understands itself to be in the energy business and not just in the oil and gas business. In 2011, after buying a solar power company, SunPower, Total formed a social business called 'Awango by Total' to provide solar-powered lanterns to poor communities in developing countries. Today more than 5 million people, mostly in rural areas in subSaharan Africa and Asia, have solar lamps that enable a quality of life heretofore unavailable. The goal is to have these lamps available to 25 million people by 2020 . The company is targeting improved solar kits that will enable televisions, fans and cooking stoves to be powered. Following the model of a social business, Awango by Total ploughs profits back into the company to provide research for further products.

\section{Conclusion}

While it is clear that there is no full-blown theory of business that informs a theory of the firm and might give guidance to the new expanded set of social expectations for business, it is also clear that many business leaders are moving ahead with a vision to pursue profit and social good simultaneously. They have restoryed the purpose of business. Of the 
9600 businesses in the UN Global Compact following this vision, I have selected Total S.A. to illustrate this endeavour. To be sure, not every business accepts this expanded role of business in society. Howard Schultz of Starbucks perhaps captures the spirit of the times: "We all recognize that with every decision we make, there is a group of people that are not going to agree with us. But you must define your core purpose for being. We stand in the interest of something greater than just making money" (The New York Times, 2017). That "something greater than making money" for the signatories of the Global Compact and many other businesses is the challenge of promoting and protecting the human dignity of stakeholders, a restorying of the role of business in society. Meeting the challenge is not only possible, it's happening.

\section{References}

Annan, K. (1999). Business and the UN: a global compact of shared values and principles. Vital Speeches at the Day, 6(9):260-261.

Aristotle. (1926). Nicomachaen Ethics. (Transl. M. Ostwald). New York: Macmillan Publishing Company.

Boje, D.M. (1995). Stories of the storytelling organization: a postmodern analysis of Disney as "TamaraLand". Academy of Management Journal, 38(4):997-1035. https://doi.org/10.2307/256618

Boyee, M.E. (1996). Organizational story and storytelling: a critical review. Journal of Organizational Change Management, 91(5):5-26.

Denning, S. (2006). Effective storytelling: strategic business narrative techniques. Strategy \& Leadership, 34(1): 42-48. https://doi.org/10.1108/10878570610637885

Donaldson, T. \& Walsh, J. (2015). Toward a theory of business. Research in Organizational Behavior, 35:181-207. https://doi.org/10.1016/j.riob.2015.10.002

Driscoll, C. \& McKee, M. (2007). Restorying a culture of ethical and spiritual values: A role for leader storytelling. Journal of Business Ethics, 73:205-217. https://doi.org/10.1007/s10551-006-9191-5

Fleming, D. (2001). Narrative leaderships using the power of stories. Strategy \& Leadership, 29(4):34-46. https://doi.org/10.1108/sl.2001.26129dab.002

Freeman, R.E. (1984). Strategic Management: A Stakeholder Approach. Boston: Pitman.

Friedman, M. (1962). Capitalism and Freedom. Chicago: University of Chicago Press.

Friedman, M. (1970). The social responsibility of business is to increase its profits. The New York Times Magazine, 13 September.

Gates, B. (2008). A new approach to capitalism. In: M. Kinsley (ed.). Creative capitalism: a conversation with Bill Gates, Warren Buffett and other economic leaders. New York: Simon \& Schuster. 7-39.

Globe Scan (1999). The Millennium Poll on Corporate Social Responsibility. http://www.globescan.com/wpcontent/uploads/2018/01/Globescan_MillenniumPoll_1999_FullReport.pdf

Hauerwas, S. (1975). Character and the Christian life: a study in theological ethics. San Antonio: Trinity University Press.

Kanter, R.M. (2011). How great companies think differently. Harvard Business Review, 89(11):68.

Mackey, J. \& Sisodia, R. (2013). Conscious capitalism: liberating the heroic spirit of business. Cambridge, Mass.: Harvard Business Review Press.

McClendon, Jr., J.W. (1974). Biography as theology. Nashville: Abingdon.

Morsink, J. (1999). The Universal Declaration of Human Rights: Origins drafting, and intent. Philadelphia: University of Pennsylvania Press. https://doi.org/10.1353/hrq. 1999.0052

Santoro, M.A. (1998). Engagement with integrity: What we should expect multinational firms to do about human rights in China. Business and the Contemporary World, 10(1):25-54. 
The New York Times. (2017). Executive powers: CEOs are speaking out on social issues. Recasting the role of business in national debates. 20 August:B1 \& B5.

Total S.A. (2017). https://www.total.com/en/commitment

UN Preamble. (2018). www.un.org/en/sections/un-charter/preamble/index.html

United Nations Global Compact (UNGC). (2013). The Blueprint for Corporate Sustainability Leadership. https://www.unglobalcompact.org/docs/news_events/8.1/Blueprint.pdf

UNGC. (2015a). Sustainable development goals. https://www.un.org/sustainabledevelopment

UNGC. (2015b). Sustainable development goals. https://www.un.org/sustainabledevelopment/energy/

UNGC. (2015c). Sustainable development goals. https://www.un.org/sustainabledevelopment/climate-change-2/

UNGC. (2016). White paper. The UN Global Compact ten principles and the Sustainable Development Goals: connecting, crucially. https://www.unglobalcompact.org/docs/about_the_gc/White_Paper_Principles_ SDGs.pdf

UNGC. (2018). Action platforms. https://www.unglobalcompact.org/sdgs/action-platforms

UNPRME. (2007). www.unprme.org/about-prme/the-sixprinciples.php

Williams, O.F. (2004). The UN Global Compact: the challenge and the promise. Business Ethics Quarterly, 14(4):755-774. https://doi.org/10.5840/beq200414432

Williams, O.F. (2014). Corporate social responsibility: the role of business in sustainable development. London and New York: Routledge.

Williams, O.F. \& Houck, J. (1978). Full value: Cases in Christian business ethics. New York: Harper \& Row.

Zadek, S. (2004). The path to corporate responsibility. Harvard Business Review, 82(12):2-10. 